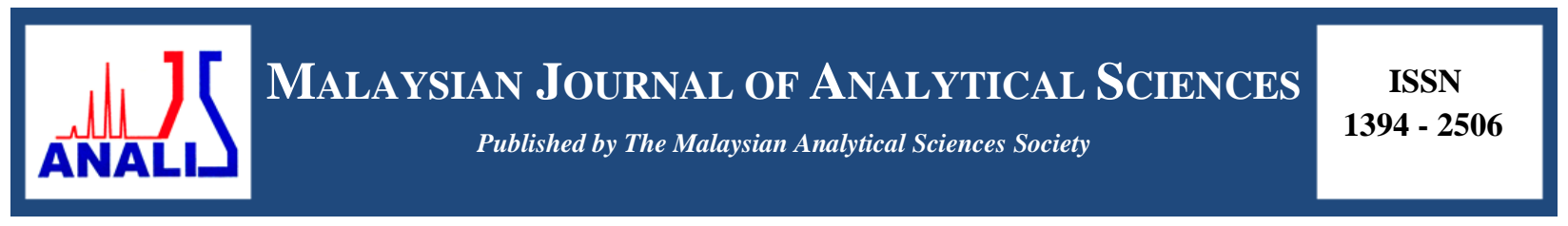

\title{
TOTAL FLAVONOIDS AND PHENOLIC CONTENTS OF STICKY AND HARD PROPOLIS FROM 10 SPECIES OF INDO-MALAYAN STINGLESS BEES
}

\author{
(Jumlah Kandungan Flavonoid dan Fenolik dalam Propolis yang Melekit dan Keras daripada \\ 10 Spesis Lebah Kelulut Indo-Malayan) \\ Norafiza Awang ${ }^{1}$, Nora'aini Ali ${ }^{1}$, Fadzilah Adibah Abd Majid ${ }^{2}$, Sofiah Hamzah $^{1}$, Shamsul Bahri Abd Razak $^{3}$ \\ ${ }^{1}$ School of Ocean Engineering \\ ${ }^{2}$ Institute Marine Biotechnology \\ ${ }^{3}$ School of Food Science and Technology \\ Universiti Malaysia Terengganu, 21030 Kuala Nerus, Terengganu, Malaysia \\ *Corresponding author: noraaini@umt.edu.my
}

Received: 16 April 2017; Accepted: 7 March 2018

\begin{abstract}
The present works aimed to identify the total flavonoids content (TFC), total phenolic content (TPC) and antioxidant activities of sticky and hard propolis of 10 species of Indo-Malayan stingless bee's namely Heterotrigona itama (H. itama), Geniotrigona thoracica (G. thoracica), Homotrigona aliceae (H. aliceae), Homotrigona fimbriata (H. fimbriata), Tetrigona apicalis (T. apicalis), Tetrigona vidua (T. vidua), Tetrigona peninsularis (T. peninsularis), Lophotrigona canifrons (L. canifrons), Tetrigona melanoleuca (T. melanoleuca), and Tetrogona binghami (T. binghami). The ethanolic extracts of these propolis (EEP) were prepared and analysed for the determination of TFC using aluminium chloride method, TPC and antioxidant activity using the 1,1-diphenyl-2-picrylhydrazyl (DPPH) free radical-scavenging assay system. The sticky propolis showed $91 \%$ of TFC and $49 \%$ of TPC higher than the hard propolis. Interestingly, the sticky propolis had stronger antioxidant activities than hard propolis for all species. The highest antioxidant activities were found in sticky propolis of $\mathrm{H}$. itama which is $85 \%$ of DPPH degradation while the lowest antioxidant activity was found in the hard propolis of L. conifrons which is 5\% of DPPH degradation. In conclusion, the data gathered in this study revealed that propolis from all 10 types of stingless bees' species are biologically active. The selection of propolis for further development can be based on its biological activities, which vary according to the species of stingless bees.
\end{abstract}

Keywords: stingless bees, propolis, total flavonoids content, total phenolic content

Abstrak

Kajian ini bertujuan untuk mengenal pasti jumlah kandungan flavonoid, jumlah kandungan fenolik dan aktiviti antioksidan dalam propolis yang melekit dan keras daripada 10 spesis lebah kelulut Indo-Malayan iaitu Heterotrigona itama (H. itama), Geniotrigona thoracica (G. thoracica), Homotrigona aliceae (H. aliceae), Homotrigona fimbriata (H. fimbriata), Tetrigona apicalis ( $T$. apicalis), Tetrigona vidua (T. vidua), Tetrigona peninsularis ( $T$. peninsularis), Lophotrigona canifrons ( $L$. canifrons), Tetrigona melanoleuca (T. melanoleuca), dan Tetrogona binghami (T. binghami). Ekstrak etanolik propolis ini (EEP) telah disediakan dan dianalisis bagi menentukan jumlah kandungan flavonoid (TFC) dengan menggunakan kaedah aluminium klorida, jumlah kandungan fenolik (TPC) dan aktiviti antioksidan menggunakan 1,1-difenil-2-pikrilhidrazil (DPPH) sistem ujian berasaskan radikal bebas. Propolis yang melekit menunjukkan TFC $91 \%$ dan TPC $49 \%$ lebih tinggi daripada propolis keras. Menariknya, propolis yang melekit mempunyai aktiviti antioksidan yang lebih kuat daripada propolis keras untuk semua spesies. Aktiviti antioksidan tertinggi didapati dalam propolis yang melekat $\mathrm{H}$. itama $85 \%$ degradasi DPPH manakala aktiviti antioksidan paling rendah didapati dalam propolis keras L.conifrons 5\% degradasi DPPH. Kesimpulannya, data yang dikumpul dalam kajian 
ini mendedahkan bahawa propolis dari semua 10 jenis lebah adalah spesies biologi aktif. Pemilihan propolis untuk pembangunan selanjutnya boleh berdasarkan aktiviti biologinya, yang bervariasi mengikut spesies lebah tanpa ragu-ragu.

Kata kunci: lebah kelulut, propolis, jumlah kandungan flavonoid, jumlah kandungan fenolik

\section{Introduction}

According to EPU (2009), Malaysia is one of the world's 12-mega biodiversity countries, with a highly rich natural and environmental resources [1,2]. One of these natural sources is the species of stingless bees. Stingless bees reap resins from different types of plant and take them back to the hive where they are then used as propolis (propolis is an apicultural term for the resins when utilized by stingless honey bees inside a hive) [3,4].

Propolis is an important material, which is used by stingless bees to protect their hive and also to support their honey pot. The glue-like propolis is composed of various types of plant resins, waxes and pollens. Propolis contains a classification of chemical compounds, for example, polyphenols like flavonoid aglycones, phenolic acids and their esters, phenolic aldehydes, alcohols and ketones, sesquiterpene quinones, coumarins, steroids, amino acids and inorganic compounds. Moreover, propolis samples contain more than 160 constituents, and their structure contrasts incredibly because of the varieties of their topographical and natural birthplace [5-7]. The presence of different types of plants will also influence the types of physical and chemical properties in the propolis.

Malaysian stingless bees produce two types of propolis, the sticky and hard propolis. Figure 1 (a) and (b) shows the difference between sticky and hard propolis of stingless bees. The most common domesticated species in Malaysia are Heterotrigona itama (H. itama) and Geniotrigona thoracica (G. thoracica) producing sticky propolis. The stingless bees that produce hard propolis are Homotrigona aliceae (H. aliceae), Homotrigona fimbriata $(H$. fimbriata), Tetrigona apicalis (T. apicalis), Tetrigona vidua (T. vidua), Tetrigona peninsularis (T. peninsularis), Lophotrigona canifrons (L. canifrons), Tetrigona melanoleuca (T. melanoleuca), and Tetrogona binghami (T. binghami) (refer Table 1).

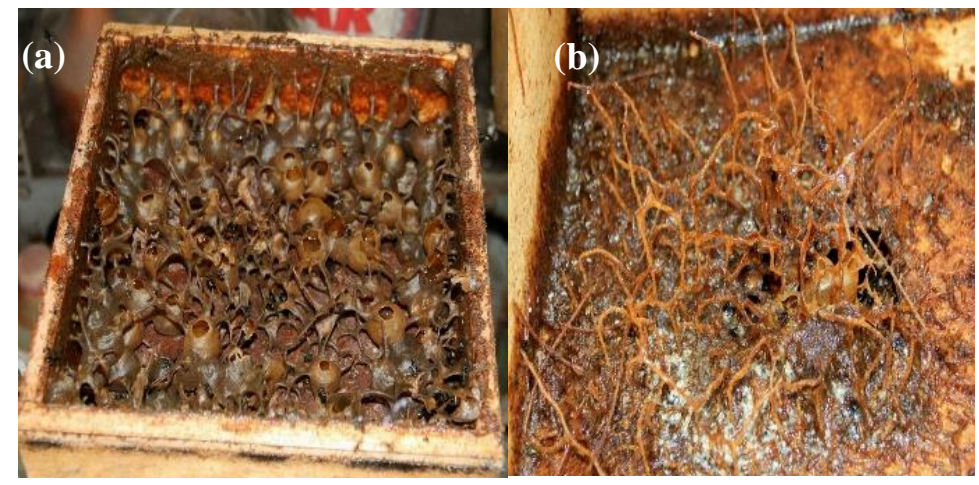

Figure 1. Types of propolis (a) sticky propolis (b) hard propolis

Propolis was found to have different types of medicinal activities such as anti-septic, anti-bacterial, anti-cancer, anti-mycotic, anti-inflammatory, anti-protozoan, astringent, and anti-viral [8-10]. Consequently, propolis based health products are claimed to have high amount of nutrients and antioxidants and are beneficial for health and wellbeing. It is proposed that the propolis biological activities mainly depend on the presence of a large amount of flavonoids [8-10].

The biological activities of stingless bee propolis in Malaysia are not yet well studied. Some of activities, such as antioxidant properties have been found in the ethanolic extracts of propolis, and recently, H. itama propolis was reported to have the highest inhibition percentage of anti-radical activity (DPPH), followed closely by G. thoracica propolis [11]. At present, hardly any available literature reports the studies on the antioxidant property or chemical 
constituents of hard propolis. Therefore, this study was conducted to initiate the screening of nutraceutical properties of sticky and hard propolis from the different stingless bees' species in Malaysia.

In this study, the scavenging of diphenyl picrylhydrazyl (DPPH) was conducted through colorimetric method for determining free radical-scavenging activity. The aluminium nitrate method was conducted to identify the total flavonoid content, and the Folin-Ciocalteu method was used to determine the total phenolic content. It is expected that there will be variations in the nutraceutical values of the propolis from different species of stingless bees.

\section{Chemicals and reagents}

\section{Materials and Methods}

Aluminium chloride $\left(\mathrm{AlCl}_{3}\right)$ and all solvents were purchased from Merck, Germany. 1,1-diphenyl-2-picrylhydrazyl (DPPH) and Folin Ciocalteu's reagent were purchased from Sigma-Aldrich, USA. All chemicals and reagents used were analytical grade.

\section{Collection and preparation of propolis}

The propolis samples from ten species of Indo-Malayan stingless bees collected from Taman Pertanian Sekayu, Terengganu in April 2016. Each sample was freezing in $-10^{\circ} \mathrm{C}$, then ground to powder and kept desiccated up to their processing.

\section{Extraction}

Crude propolis $(10 \mathrm{~g})$ was extracted with $70 \%$ ethanol $(100 \mathrm{ml})$ through mixing for 24 hours at room temperature. The crude extract was recovered by centrifugation at $27000 \mathrm{x}$ g for 20 minutes. The insoluble portion was then separated by filtration using filter paper and the filtrates were kept in a freezer at $-10{ }^{\circ} \mathrm{C}$ overnight. Then, they are filtered again to reduce the wax content of the extracts. The solvent was evaporated off in a vacuum oven at a temperature of $60^{\circ} \mathrm{C}$ to obtain dry ethanolic extract.

\section{Preparation of standard solution}

Gallic acid and Quercetin $10 \mathrm{mg}$ were accurately weighed into a $10 \mathrm{ml}$ volumetric flask, and were dissolved in 10 $\mathrm{ml}$ ethanol. The solution was made up to $10 \mathrm{ml}$ with the same solvent $[1 \mathrm{mg} / \mathrm{ml}]$.

\section{Determination of total phenolic content}

Total Phenolic Content (TPC) in EEP were determined according to the Folin-Ciocalteu colorimetric method [1213]. Gallic acid was used as a standard, and the total phenolics were expressed as $\mathrm{mg} / \mathrm{g}$ Gallic Acid equivalents (GAE). Consequently, $1 \mathrm{ml}$ of standard solution of concentration 1.95, 3.9, 7.8, 15.63, 31.25 and $62.5 \mathrm{mg} / \mathrm{ml}$ of gallic acid were prepared in ethanol. $1 \mathrm{mg} / \mathrm{ml}$ propolis extracts with concentration of 1:10 (0.1) were also prepared in ethanol and $0.5 \mathrm{ml}$ of each sample were introduced into the test tubes and mixed with $0.5 \mathrm{ml}$ of the FolinCiocalteu reagent and $0.5 \mathrm{ml}$ of $7.5 \%$ sodium carbonate, $\mathrm{Na}_{2} \mathrm{CO}_{3}$. The absorbance was read at $760 \mathrm{~nm}$ after 2 hours of incubation in the dark at room temperature.

\section{Determination of total flavonoids content}

Aluminium chloride method was used for flavonoids determination. In this method, Quercetin was used as standard and flavonoid contents were measured as Quercetin equivalent. $1 \mathrm{ml}$ of standard solution of concentration 1.95, 3.9, $7.8,15.63,31.25,62.5$ and $125 \mathrm{mg} / \mathrm{ml}$ of Quercetin were prepared in ethanol. $1 \mathrm{mg} / \mathrm{ml}$ of propolis extracts, with the concentration of 1:10 (0.1) were also prepared in ethanol and $0.5 \mathrm{ml}$ of each sample were introduced into the test tubes and mixed with $0.5 \mathrm{ml}$ of fresh $2 \%$ of Aluminium chloride, $\mathrm{AlCl}_{3}$ ethanol solution. After being placed in the dark at room temperature for one hour, the absorbance was measured at $420 \mathrm{~nm}$ [14].

\section{DPPH radical scavenging activity}

The DPPH free radical scavenging activity was evaluated using Blois method with slight modification [15]. The DPPH solution $(0.2 \mathrm{mM})$ was prepared in methanol and $100 \mu \mathrm{l}$ to $100 \mu \mathrm{l}$ of the sample extracts, 5.0, 2.5, 1.25, 0.6, $0.3,0.16,0.08,0.04,0.02,0.01,0.005(\mathrm{mg} / \mathrm{ml})$. The resulting extracts solutions were kept at room temperature in a dark place for 30 minutes. The absorbance was measured at $515 \mathrm{~nm}$. Moreover, the radical scavenging activity was 


\section{Norafiza et al: TOTAL FLAVONOIDS AND PHENOLIC CONTENTS OF STICKY AND HARD PROPOLIS FROM 10 SPECIES OF INDO-MALAYAN STINGLESS BEES}

expressed as the inhibition percentage, and was calculated using the following formula, while Ascorbic acid was used as a positive control:

$$
\% \text { Radical scavenging activity }=[(\text { Abs Control }- \text { Abs Sample }) /(\text { Abs Control }] \times 100 \%
$$

\section{Results and Discussion}

\section{Physical evaluation of 10 species of Indo-Malayan stingless bees}

Stingless bees produce propolis as part of their defense system to protect their hives from invaders and microbial attacks. In this study, propolis produced by 10 species of stingless bees were collected and each different species of stingless bee has different physical attributes, such as their types of propolis base. Table 1 shows the different species of Indo-Malayan stingless bees propolis and their propolis physical base.

Table 1. Types of physical base propolis of stingless bee

\begin{tabular}{|c|c|}
\hline Sticky Propolis & Hard Propolis \\
\hline $\begin{array}{l}\text { Heterotrigona itama }(\text { H. itama }) \text { and } \\
\text { Geniotrigona thoracica }(G . \text { thoracica) }\end{array}$ & $\begin{array}{l}\text { Homotrigona aliceae (H. aliceae), Homotrigona } \\
\text { fimbriata (H. fimbriata), Tetrigona apicalis (T. } \\
\text { apicalis),Tetrigona vidua (T. vidua),Tetrigona } \\
\text { peninsularis (T. peninsularis), Lophotrigona canifrons } \\
\text { (L. canifrons), Tetrigona melanoleuca (T. } \\
\text { melanoleuca), and Tetrogona binghami (T. binghami). }\end{array}$ \\
\hline
\end{tabular}

TFC and TPC of propolis stingless bees

The TFC was calculated from the regression equation of the standard plot $\left(y=0.016 x-0.0171, r^{2}=0.997\right)$ and is expressed as quercetin equivalents $(\mathrm{QE})$. The flavonoid contents can be determined in the sample extract by using aluminium chloride method at wavelength of $415 \mathrm{~nm}$ [16]. Several studies reported that the total flavonoids content that present in propolis extract significantly contributed to their antioxidant activities [7, 17-18]. It has been shown to be good scavengers of most oxidizing molecules, including single oxygen and various free radicals.

The TPC was determined using the Folin-Ciocalteu reagent. The result of TPC was calculated from the regression equation of the standard plot $\left(y=0.0417 x+0.0299, r^{2}=0.999\right)$. The TPC in propolis play the key role as primary antioxidants or free radical scavengers. The antioxidant activity of the TPC is mainly due to their redox properties, which an important role in absorbing and neutralizing free radicals, quenching singlet and triplet oxygen or decomposing peroxides [19]. In this regard, the bioactivity of phenolics may be related to their ability to chelate metals, inhibit. lipoxygenase and scavenge free radicals [20-21]. TFC and TPC of each stingless bee species are summarized in Figure 2 and Table 2. 


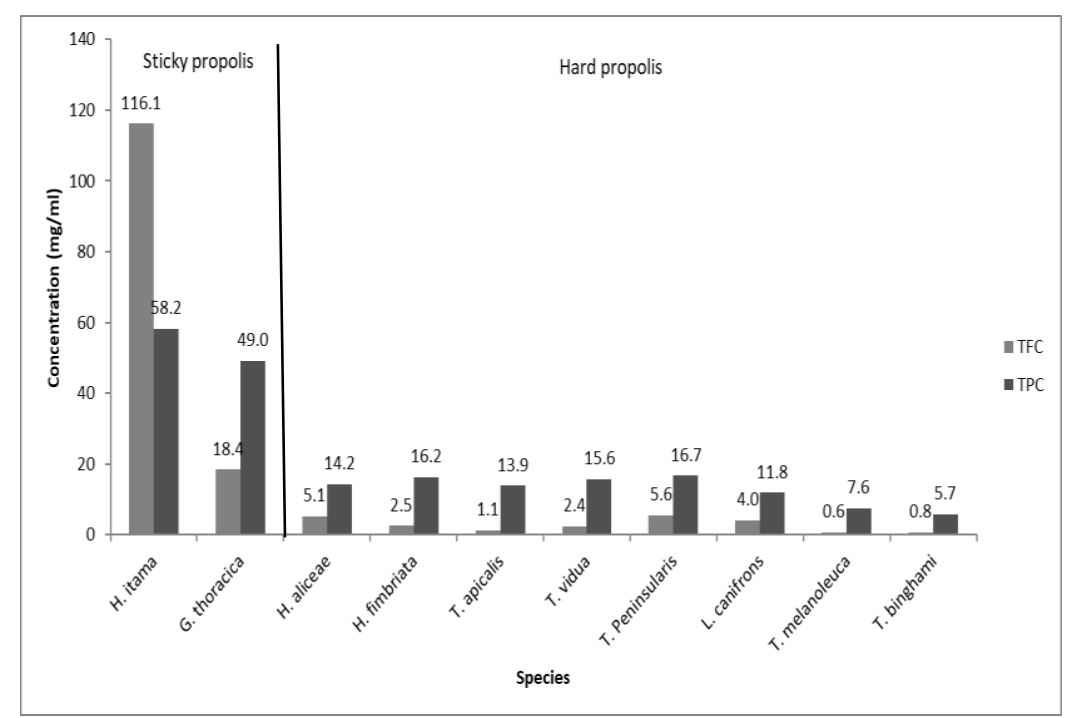

Figure 2. Total flavonoids content and total phenolic content of stingless bees' species

Table 2. Mean values and standard deviations of TFC and TPC found in sticky and hard propolis extracts

\begin{tabular}{lll}
\hline Samples Extracts & TFC $(\mathbf{m g} / \mathbf{m l})$ & TPC $(\mathbf{m g} / \mathbf{m l})$ \\
\hline H. itama & $116.1 \pm 3.93$ & $58.2 \pm 2.97$ \\
G. thoracica & $18.4 \pm 0.69$ & $49.0 \pm 1.03$ \\
H. aliceae & $5.1 \pm 0.32$ & $14.2 \pm 0.52$ \\
H. fimbriata & $2.5 \pm 0.47$ & $16.2 \pm 1.24$ \\
T. apicalis & $1.1 \pm 0.29$ & $13.9 \pm 1.05$ \\
T. vidua & $2.4 \pm 0.45$ & $15.6 \pm 0.61$ \\
T. Peninsularis & $5.6 \pm 0.30$ & $16.7 \pm 0.32$ \\
L. canifrons & $4.0 \pm 0.20$ & $11.8 \pm 1.12$ \\
T. melanoleuca & $0.6 \pm 0.06$ & $7.6 \pm 0.35$ \\
T. binghami & $0.8 \pm 0.34$ & $5.7 \pm 0.45$ \\
\hline
\end{tabular}

The maximum concentration of TFC found in the ethanolic extract of propolis was $116.1 \mathrm{mg} / \mathrm{ml}$ from the H. itama species, while the lowest comes from the T. melanoleuca species with $0.6 \mathrm{mg} / \mathrm{ml}$. The amount of TPC was found to be high in $H$. itama propolis extract $(58.2 \mathrm{mg} / \mathrm{ml})$, compared to the TPC, which was lower in the sample of $T$. binghami propolis extract $(5.7 \mathrm{mg} / \mathrm{ml})$. Meanwhile, for both the sticky base propolis of $H$. itama propolis extract and G. thoracica propolis extract, the H. itama propolis extract contains high amount of flavonoids content, compared to G. thoracica propolis extract which were $116.1 \mathrm{mg} / \mathrm{ml}$ and $18.4 \mathrm{mg} / \mathrm{ml}$, respectively. Similarly, the $H$. itama propolis extract possesses large quantities of phenolic content compared to G. thoracica propolis extract, which were $58.2 \mathrm{mg} / \mathrm{ml}$ and $18.4 \mathrm{mg} / \mathrm{ml}$, respectively. The results obtained from the present study show that the propolis extract of $H$. itama species, which contains the highest amount of TFC and TPC, followed by propolis extract of G. thoracica species, exhibited the greatest antioxidant activity. The sticky propolis showed $91 \%$ of TFC and $49 \%$ of TPC higher than the hard propolis. Previous study has been reported that TPC and TFC of $H$. itama was higher than G. thoracica [21]. Thus, both sticky base propolis of H. itama and G. thoracica species have more potential to be developed as part of new drugs, compared to harden base propolis of H. aliceae, H. fimbriata, $T$. apicalis, T. vidua, T. peninsularis, L. canifrons, T. melanoleuca, and T. binghami. Moreover, it is clearly understood that the phenolic compounds and flavonoids are the chief components of propolis and account for 


\section{Norafiza et al: TOTAL FLAVONOIDS AND PHENOLIC CONTENTS OF STICKY AND HARD PROPOLIS FROM 10 SPECIES OF INDO-MALAYAN STINGLESS BEES}

antioxidant properties. The variation in the TFC of propolis is mainly attributable to the difference in the preferred regional plants pollinated by the stingless bees. In this regard, the content of flavonoids and other phenolic substances are suggested as able to prevent cancer and heart diseases [22].

\section{Free radical-scavenging activity}

In order to evaluate the dose-response curve for the free radical-scavenging activity of ethanol extract of propolis, a method based on the reduction of DPPH a stable free radical, was used. The use of DPPH to scavenge radicals has advantages, including being easy to use, highly sensitive and able to analyze of large numbers of samples in a short time. The DPPH is a free radical compound that has been widely used to analyze the free radical scavenging ability of various samples [23]. It is approved that the DPPH free radical scavenging through antioxidants is caused by their hydrogen-donating ability [24]. To evaluate the scavenging effect of DPPH on ethanol extract of propolis, DPPH inhibition was investigated and the results are shown as relative activities against control, as well as the variation of inhibition percentage. As shown in Figure 3, ascorbic acid has the highest inhibition percentage (antiradical activity), closely followed by $H$. itama and the $L$. canifrons has the lowest and the defenses are statistically significant. Meanwhile, although ascorbic acid showed higher scavenging activity for all tested samples, ethanol extracts of propolis of sticky propolis still showed good free radical scavenging activity compared to ethanol extracts of propolis of harden propolis.

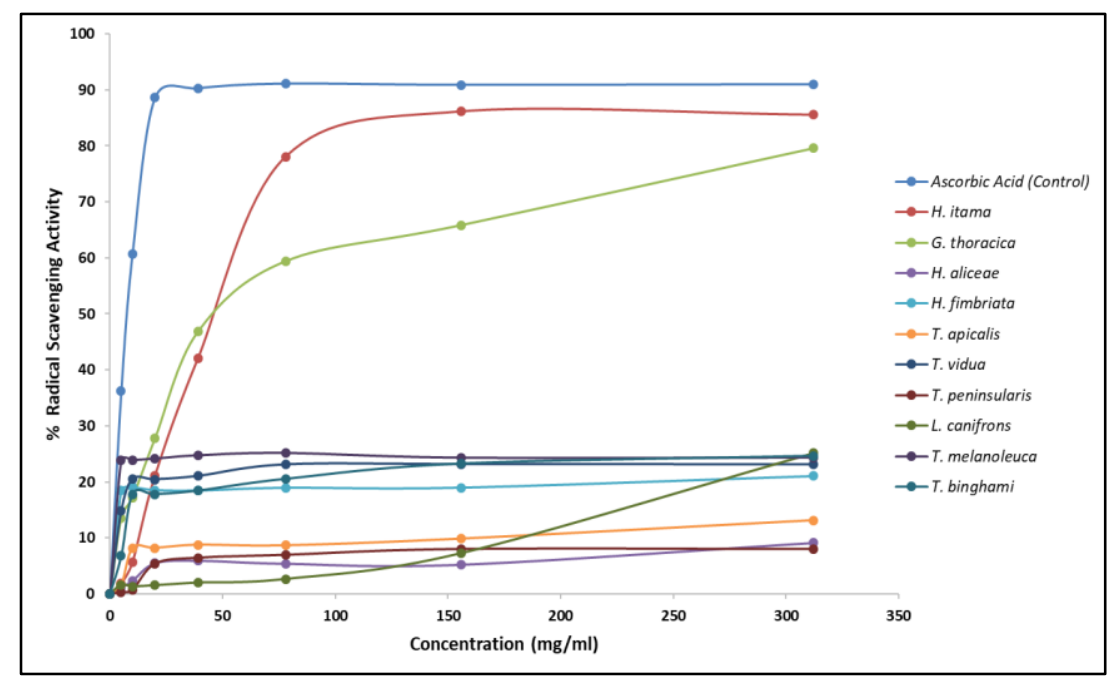

Figure 3. Free radical-scavenging activity of propolis stingless bees

In general, these findings demonstrate that the antioxidant activity was correlated with total polyphenol contents in propolis samples. In this light, the antioxidant activity of propolis is due to the presence of phenolic acids and flavonoid compounds, which have ability to reduce free radical formation, scavenge free radicals and chelate metal ions [18]. The highest antioxidant activities were found in sticky propolis of $H$. itama which is $85 \%$ of DPPH degradation while the lowest antioxidant activity was found in the hard propolis of $L$. conifrons which is $5 \%$ of DPPH degradation. The results showed that the sticky propolis extract from the H. itama and G. thoracica species possess higher free radical-scavenging activity which shows it suitability to be used as a source of natural antioxidants, compared to hard propolis [25]. The reasons behind the marked higher radical scavenging activity exhibited by different types of propolis are probably due to their resin plant origin, climate, and resin collection time by the stingless bees.

\section{Conclusion}

This study shows that stingless bees species play a role in determining the phytochemical and antioxidant activity. This is the first report on the antioxidant activity of Malaysian propolis which, presents the comparison between sticky and hard propolis, particularly two commonly sticky propolis produced by $H$. itama and $G$. thoracica species 
and the other hard propolis of $H$. aliceae, H. fimbriata, T. apicalis, T. vidua, T. peninsularis, L. canifrons, T. melanoleuca, and T. binghami species. In this regard, the propolis samples have strong antioxidant activities, and the strongest activity was found in the H. itama propolis which was came from sticky propolis. Consequently, the data presented in this study will shed some light on the potential of propolis produced by stingless bees in Malaysia. In this light, further investigations on the identification of marker compounds should be carried out to be use in propolis standardization.

\section{Acknowledgement}

This paper is fully supported by Fundamental Research Grant Scheme (Vot 59438), Ministry of Higher Education (MOHE) and University Malaysia Terengganu by the approved fund.

\section{References}

1. Prime Minister's Department, Malaysia (2009). Economic planning unit. Access from http://www.epu.gov.my/ web [Online 18 November 2009].

2. Talaat, W. I. A. W., Tahir N. M. and Mohd L. H. (2012). Sustainable management of forest biodiversity and the present Malaysian policy and legal framework. Journal of Sustainable Development, 5(3): 76-83.

3. Bankova, V., Trusheva, B. and Popova M. (2008). new developments in propolis chemical diversity studies. Transworld Research Network: pp. 1-13.

4. Banskota A. H., Tezuka Y. and Kadota S. (2001). Recent progress in pharmacological research of propolis. Phytotherapy Research, 15(7): 561-571.

5. Ghisalberti, E. L. (1979). Propolis: A review. Bee World, 60: 59-84.

6. Greenaway, W., May, J., Scaysbrook, T. and Whatley, F. R. (1991). identification by gas chromatography-mass spectrometry of 150 compounds in propolis. Zeitschrift für Naturforschung, 46(1-2): 111-121.

7. Bonvehí Josep, S. and Coll Francesc, V. (1994). Phenolic composition of propolis from China and from South America. Zeitschrift für Naturforschung, 49(11-12): 712-718.

8. Bankova, V., Dyulgerov, A., Popov, S. and Marekov, N. (1987). A GC/MS study of the propolis phenolic constituents. Zeitschrift für Naturforschung, 42(1-2): 147-151.

9. Bonvehí, J. S., Coll, F. V. and Jordà, R. E. (1994). The composition, active components and bacteriostatic activity of propolis in dietetics. Journal of the American Oil Chemists' Society, 71(5): 529-532.

10. Vennat, B., Arvouet-Grand, A., Gross, D. and Pourrat, A. (1995). Qualitative and quantitative analysis of flavonoids and identification of phenolic acids from a propolis extract. Journal De Pharmacie De Belgique, 50: 438-444.

11. Ibrahim, N., Farah Shakila Mohd Niza, N., Rodi, M., Jamil Zakaria, A., Ismail, Z. and Mohd, K. (2016). Chemical and biological analyses of Malaysian stingless bee propolis extracts. Malaysian Journal of Analytical Sciences, 20(2): 413-422.

12. Singleton, V. L., Orthofer, R. and Lamuela-Raventós, R. M. (1999). Analysis of total phenols and other oxidation substrates and antioxidants by means of Folin-Ciocalteu reagent. Methods in Enzymology, 299: 152178.

13. Kumazawa, S., Taniguchi, M., Suzuki, Y., Shimura, M., Kwon, M. S. and Nakayama, T. (2002). Antioxidant activity of polyphenols in carob pods. Journal of Agricultural and Food Chemistry, 50(2): 373-377.

14. Chang, C., Yang, M. and Wen, H. (2002). Estimation of total flavonoid content in propolis by two complementary colorimetric methods. Journal of Food Drug Analysis, 10(3): 178-182.

15. Blois, M. S. (1958). Antioxidant determinations by the use of a stable free radical. Nature, 181: 1199-1200.

16. Abu Bakar, M. F., Mohamed, M., Rahmat, A. and Fry, J. (2009). Phytochemicals and antioxidant activity of different parts of bambangan (Mangifera pajang) and Tarap (Artocarpus odoratissimus). Food Chemistry, 113(2): 479-483.

17. Isla, M. I., Nieva Moreno, M. I., Sampietro, A. R. and Vattuone, M. A. (2001). Antioxidant activity of argentine propolis extracts. Journal of Ethnopharmacology, 76(2): 165-170.

18. Kumazawa, S., Hamasaka, T. and Nakayama, T. (2004). Antioxidant activity of propolis of various geographic origins. Food Chemistry, 84(3): 329-339.

19. Osawa, T. (1994). Novel natural antioxidants for utilization in food and biological systems. postharvest biochemistry of plant food-materials in the tropics. Japan Scientific Press, Tokyo, Japan: pp. 241-251. 
20. Mallavadhani, U. V., Sudhakar, A. V. S., Satyanarayana, K. V. S., Mahapatra, A., Li, W. and vanBreemen, R. B. (2006). Chemical and analytical screening of some edible mushrooms. Food Chemistry, 95(1): 58-64.

21. Ibrahim, N., Zakaria, A. J., Ismail, Z. and Mohd, K. (2016). Antibacterial and phenolic content of propolis produced by two Malaysian stingless bees, Heterotrigona itama and Geniotrigona thoracica. International Journal of Pharmacognosy and Phytochemical Research, 8(1): 156-161.

22. Lin, S. Y., Liu, H. Y., Lu, Y. L. and Hou, W. C. (2005). Antioxidant activities of mucilages from different Taiwanese yam cultivars. Botanical Bulletin of Academia Sinica, 46: 183-188.

23. Kahkonen, M. P., Hopia, A. I., Vuorela, H. J., Rauha, J. P., Pihlaja, K., Kujala, T. S. and Heinonen, M. (1999). Antioxidant activity of plant extracts containing phenolic compounds. Journal of Agricultural and Food Chemistry, 47(10): 3954-3962.

24. Hatano, T., Takagi, M., Ito, H. and Yoshida, T. (1997). Phenolic constituents of liquorice. VII. A new chalcone with a potent radical scavenging activity and accompanying phenolics from liquorice. Chemical and Pharmaceutical Bulletin, 45(9): 1485-1492.

25. Tang, S. Z., Kerry, J. P., Sheehan, D. and Buckley, D. J. (2002). Antioxidative mechanisms of tea catechins in chicken meat systems. Food Chemistry, 76(1): 45-51. 